\title{
29. PLIOCENE AND QUATERNARY DIATOMS, SILICOFLAGELLATES, SPONGE SPICULES, AND ENDOSKELETAL DINOFLAGELLATES FROM THE PHILIPPINE SEA, DEEP SEA DRILLING PROJECT LEGS 59 AND $60^{1}$
}

\author{
Erlend Martini, Geologisch-Paläontologisches Institut der Universität, \\ Frankfurt am Main, Federal Republic of Germany
}

\section{INTRODUCTION}

During Leg 59 of the Deep Sea Drilling Project five sites (Sites 447 through 451), and during Leg 6010 sites (452 through 461) were occupied, and 24 holes drilled between Okinawa and Guam in the Philippine Sea. More than 470 samples from Leg 59 and approximately 315 samples from Leg 60 were investigated for siliceous fossils other than radiolarians. All sites, with the exception of Sites $447,448,457$, and 461 , yielded representatives of the diatoms, silicoflagellates, sponge spicules, and endoskeletal dinoflagellates at particular levels, commonly in the Quaternary and at Site 451 also in the Pliocene interval. Siliceous microfossil assemblages encountered and age assignments will be discussed for each site, and a complete list of fossils for all occurrences is given in Table 1 , covering the Pliocene and Quaternary. Generally, samples were investigated in routine smear slides and with light microscope techniques. In addition, Samples 449-2-1, 42-43 cm; 451$1, \mathrm{CC} ; 451-2-1,43-44 \mathrm{~cm}$; and 459-SP 3-1, 70-71 cm were especially treated to be investigated by scanning electron microscopy. These samples are identified as such in Table 1.

Geographical positions of the DSDP holes drilled during Legs 59 and 60 are as follows (Fig. 1):

Holes 447 and 447A:

$18^{\circ} 00.88^{\prime} \mathrm{N} ; 133^{\circ} 17.37^{\prime} \mathrm{E}$ water depth 6022 meters

Holes 448 and 448A:

Site 449:

Site 450:

Site 451:

Holes 452 and 452A:

Site 453:

Holes 454 and 454A:

Site 455:

Holes 456 and 456A:
Site 457:

Site 458:

Holes 459, 459A and 459B:

Hole 460:

Hole 460A:

Holes 461 and 461A:

\section{GENERAL OCCURRENCES IN HOLES DRILLED AND CORRELATION TO CALCAREOUS NANNOPLANKTON AND/OR} RADIOLARIAN ZONES

\section{Hole 449-Parece Vela Basin}

A mass occurrence of the extremely large diatom Ethmodiscus rex was noted in the upper part of Core 2 (0.0-9.5 m), which, on the basis of radiolarians, belongs to the late Pleistocene Collosphaera tuberosa Zone of Nigrini (1971). Rare additional diatom species, silicoflagellates, and sponge spicules (Table 1) are also present at this particular level.

\section{Hole 450-Parece Vela Basin}

Diatoms occur only in the upper part of Section 1-1, and include representatives of the genera Coscinodiscus, Hemidiscus, Thalassionema, and fragments of Ethmodiscus rex. They are associated with rare silicoflagellates and sponge spicules (Table 1), and according to the radiolarian fauna containing Stylatractus universus may be placed in the late Pleistocene.

\section{Hole 451-West Mariana Ridge}

Diatoms, including the genera Ethmodiscus, Thalassiosira, Nitzschia, Asterolampra, were noted only in the lower part of Core 1, in Core 2 (5.0 to $14.5 \mathrm{~m}$ ), and in the upper part of Core 4 (at approximately $25.0 \mathrm{~m}$ ). They are associated with silicoflagellates, sponge spicules and in Sample 451-2-1, 43-44 cm with very rare endoskeletal dinoflagellates. For details see Table 1. Sample 451-1, CC can be placed in the late Pleistocene Buccinosphaera invaginata Zone of Nigrini (1971) according to the radiolarians and in Zone NN19 (Pseudoemiliania lacunosa Zone) of the calcareous nannoplankton zonation (Martini, 1971). For the lower samples radiolarian data are insufficient, but calcareous nanno-

\footnotetext{
1 Initial Reports of the Deep Sea Drilling Project, Volume 60.
} 
Table 1. Distribution of diatoms, silicoflagellates, sponge spicules, and endoskeletal dinoflagellates in the Pliocene (part of Hole 451 samples) and Quaternary of Legs 59 and 60, and indication of calcareous nannoplankton and/or radiolarian zones.

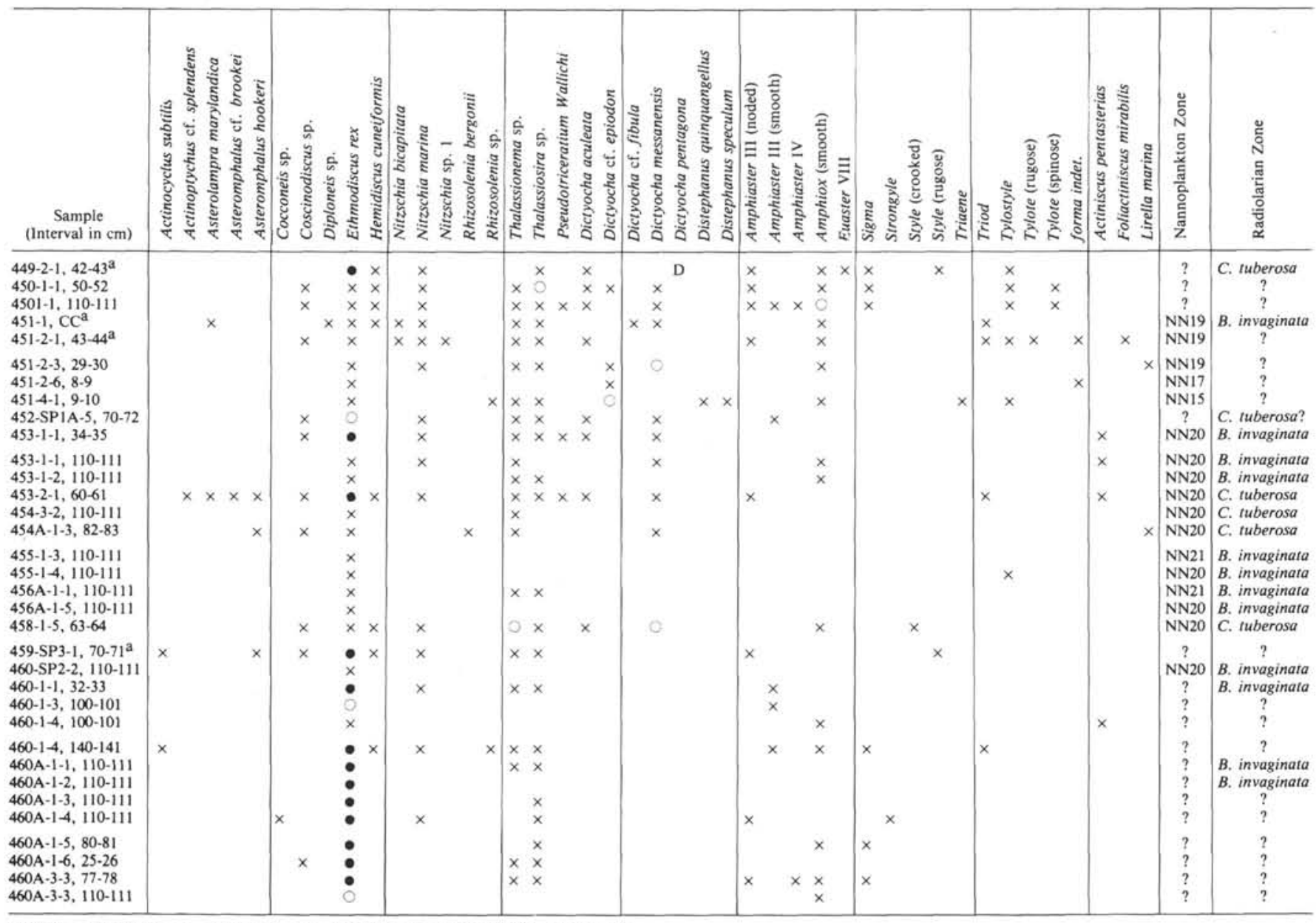

Note: $\mathrm{X}=$ rare or few, $O=$ common, $\bullet=$ abundant, $\mathrm{D}=$ displaced from older strata.

a Sample investigated with SEM.

plankton indicate the early Pleistocene Zone NN19 and the late Pliocene Zone NN17 (Discoaster pentaradiatus Zone) for the upper part of Core 2 and lowest part of Core 2 respectively (Kroenke, Scott, et al., in press). Sample 451-4-1, 9-10 $\mathrm{cm}$, on the basis of calcareous nannoplankton, belongs to the early Pliocene Zone NN15 (Reticulofenestra pseudoumbilica Zone), and may belong to the Central Pacific Dictyocha "fibula" Zone (Martini, 1976).

\section{Hole 452-Mariana Trench}

Only one sample of the site survey core SP 1A (Section 5, 70-72 cm) yielded sufficient numbers of diatoms, especially the large species Ethmodiscus rex, together with rare silicoflagellates and very rare sponge spicules (Table 1). The associated radiolarian fauna seems to indicate the late Pleistocene Collosphaera tuberosa Zone of Nigrini (1971) for this particular interval.

\section{Hole 453-Mariana Trough}

Diatoms, silicoflagellates, sponge spicules, and rare endoskeletal dinoflagellates were found in several samples from Core 1 and the upper part of Core 2 ( 0.0 to approximately $10.0 \mathrm{~m}$ ). Two mass occurrences of the large diatom Ethmodiscus rex were noted. One of these was in Sample 453-1-1, 34-35 cm, and the other in Sample 453-2-1, 60-61 cm-both belonging to the late Pleistocene nannoplankton Zone NN20 (Gephyrocapsa oceanica Zone) and to the radiolarian Buccinosphaera invaginata Zone and Collosphaera tuberosa Zone, respectively. Other diatom genera present include Coscinodiscus, Nitzschia, Hemidiscus, and Asteromphalus. For details see Table 1.

\section{Site 454-Mariana Trough}

Rare diatoms, including Ethmodiscus rex, were found in Samples 454-3-2, 110-111 cm and 454A-1-3, $82-83 \mathrm{~cm}$, both belonging to the late Pleistocene radiolarian Collosphaera tuberosa Zone and the standard nannoplankton Zone NN20. Very rare silicoflagellates and sponge spicules were also noted (Table 1).

\section{Hole 455-Mariana Trough}

A few diatoms (Ethmodiscus rex) are present in Core 1 , and are associated with very rare sponge spicules. Sample 455-1-3, 110-111 cm can be placed in the nannoplankton Zone NN21 (Emiliania huxleyi Zone), and Sample 455-1-4, 110-111 cm in Zone NN20. Both 


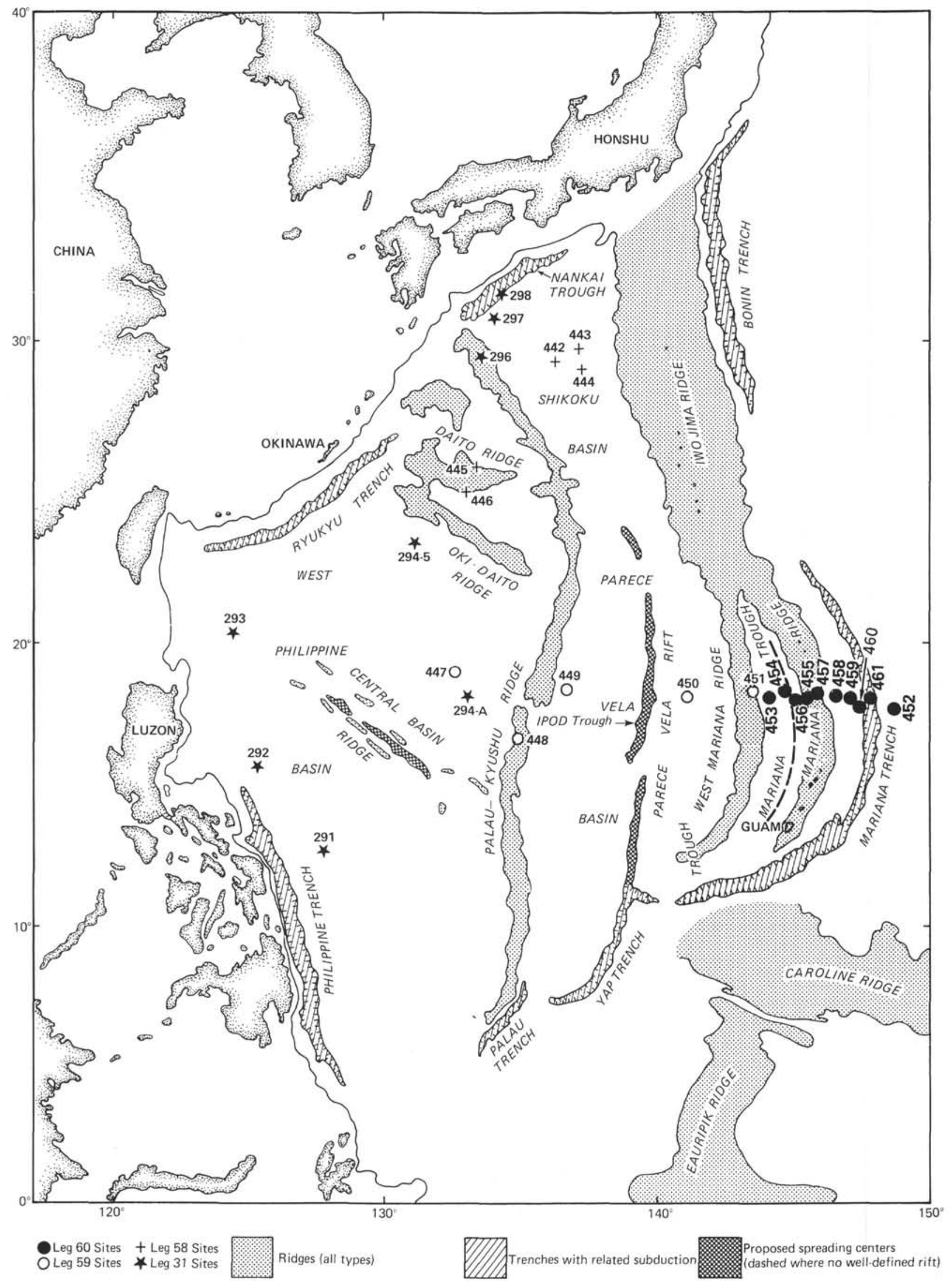

Figure 1. Location of sites drilled during Legs 59 and 60. 
samples belong to the late Pleistocene Buccinosphaera invaginata Zone of the radiolarian zonation.

\section{Site 456-Mariana Trough}

The only occurrence of diatoms, mainly Ethmodiscus rex, was noted in Samples 456A-1-1, 110-111 cm and $456 \mathrm{~A}-1-5,110-111 \mathrm{~cm}$, the first of which can be placed in nannoplankton Zone NN21 and the latter in Zone NN20. Both samples, on the basis of the radiolarians, belong to the late Pleistocene Buccinosphaera invaginata Zone.

\section{Hole 458-Mariana Fore-arc region}

Only Sample 458-1-5, 63-64 cm was found to contain a fairly well preserved diatom assemblage including the genera Ethmodiscus, Thalassionema, Coscinodiscus, and Hemidiscus, with associated silicoflagellates and very rare sponge spicules. For details see Table 1. According to the calcareous nannoplankton and radiolarian assemblages found this sample belongs to the late Pleistocene nannoplankton zone NN20 and to the Collosphaera tuberosa Zone of Nigrini (1971).

\section{Hole 459-Mariana Trench}

A mass occurrence of the diatom Ethmodiscus rex was found in the site survey core (Sample SP 3-1, 70-71 $\mathrm{cm})$. Other diatom genera are rare, but Hemidiscus, Coscinodiscus, Thalassionema, and Asteromphalus were noted (Table 1). Sponge spicules are also present in this particular sample. Associated radiolarians indicate an age not older than that corresponding to the Collosphaera tuberosa Zone (late Pleistocene).

\section{Hole 460-Mariana Trench}

This hole yielded several samples with mass occurrences of Ethmodiscus rex associated with only a few specimens of the genera Thalassiosira and Thalassionema, together with a variety of sponge spicules (Table 1) in typical solution-effected assemblages. Very rare endoskeletal dinoflagellates were found in Sample 460$1-4,140-141 \mathrm{~cm}$. Radiolarians indicate a position within the Quaternary: the Buccinosphaera invaginata Zone in the uppermost samples and probably the Collosphaera tuberosa Zone for the other samples shown in Table 1. Nannoplankton data are not available because nannoplankton are lacking in these samples.

\section{DIATOMS}

Diatoms were found in the Quaternary of nearly all sites, especially the large diatom Ethmodiscus rex, whereas other species are less well represented throughout the samples. Special attention was given to the mass occurrences of Ethmodiscus rex and its relationship to other siliceous microfossils within these Ethmodiscus oozes, which is to be discussed later. On account of scarce occurrence and often poor preservation of diatoms associated with Ethmodiscus rex, a detailed description was not attempted; some diatoms could only be identified to their genus level. A number of better preserved specimens are illustrated in Plates 1 and 2. For the other species or genera to be listed here and in Table 1, the systematic parts and plates in Schrader (1973, $1976 \mathrm{~b})$ should be consulted. The following genera and species were noted in routine smear slides and in the few samples investigated with the electron microscope:
Actinocyclus subtilis (Gregory).

One specimen was found during SEM investigation in Sample 459-SP3-1, 70-71 cm, and was tentatively placed in this species by R. Simonsen on basis of a SEM picture. Another specimen of this genus was encountered in Sample 460-1-4, 41-141 cm.

Actinoptychus cf. splendens (Shadb.).

The only specimen found in the late Pleistocene Sample 453-2-1, $60-61 \mathrm{~cm}$ has 10 alternately raised and depressed sectors.

Asterolampra marylandica Ehrenberg-Plate 1, Figure 7. Single specimens were found in Samples 451-1,CC and 453-2-1, 60-61 cm, both of Pleistocene age.

Asteromphalus cf. brookei Bailey-Plate 2, Figure 6.

A single specimen is present in Sample 453-2-1, 60-61 cm (late Pleistocene).

Asteromphalus hookeri Ehrenberg-Plate 2, Figure 3. Rare specimens were noted in the Pleistocene of Holes 453, 454A, and 459. For details see Table 1.

Cocconeis sp.

One poorly preserved specimen belonging to the genus Cocconeis was found in Sample 460-1-4, 140-141 cm (Pleistocene).

Coscinodiscus sp.

A few specimens of this genus were found in the Pleistocene of Holes 450, 451, 452, 453, 454A, 458, 459, and 460A (see Table 1). One of the better preserved specimens in Sample 454A-1-3, 82-83 $\mathrm{cm}$ was identified as Coscinodiscus africanus Janisch (Plate 2, Figure 4) by R. Simonsen.

Diploneis sp.

A broken specimen was noted in the early Pleistocene Sample 451-1, CC.

Ethmodiscus rex Wallich-Plate 1, Figures 1 through 3.

$E$. rex is the most common diatom species in the present material, and was found in all samples of Quaternary and Pliocene age listed in Table 1. Mass occurrences of this species were already described and the distribution of $E$. rex in the Pacific and Indian oceans discussed by several authors (e.g., Gombos, 1977; Jouse, et al., 1971; Kozlova, 1971; Muhina, 1971; Pimm, Garrison and Boyce, 1971; Schrader, 1973, 1976 a and b; and Simonsen, 1974). During Legs 59 and 60, mass occurrences of Ethmodiscus rex were found in the late Pleistocene of Holes 449, 453, 459, 460, and 460A, but fragments of this species were also found in the early Pleistocene and Pliocene (see Table 1). These mass occurrences are not related to only one layer as indicated by samples from Holes 453 and 460 , where mass occurrences are separated by layers with only a minor content of this species. The common or mass occurrences encountered during Leg 59 and 60 were found in sediments of areas with a present water depth of more than 4100 meters, and are especially abundant at Site 460 with a present water depth of about 6450 meters. Mikkelsen (1977) has demonstrated in laboratory experiments that Ethmodiscus is a strongly solution-resistant form, which is also concentrated in greater depth by winnowing and downslope transport. This seems in good agreement with the observations during Leg 59, where in Hole 449 the mass occurrence in Section 2-1 was a distinct 2-cm-thick pale olive layer within a pelagic dark brown clay.

Hemidiscus cuneiformis Wallich-Plate 2, Figure 1.

This sturdy species is one of the more common forms in the present material and is often found in layers with mass occurrences of Ethmodiscus rex. It is found in the Pleistocene interval of Holes $449,450,451,453,458,459$, and 460 (see Table 1).

Nitzschia bicapitata Cleve-Plate 1, Figures 4 and 6 .

Two specimens, found during SEM investigations in Samples $451-1, C C$ and $451-2-1,43-44 \mathrm{~cm}$, of early Pleistocene age belong to this species.

Nitzschia marina Grunow in Cleve and Grunow.

This species is fairly common in the Pleistocene samples of Holes $449,450,451,452,453,458,459,460$, and $460 \mathrm{~A}$. Specimens found match well with those depicted in Schrader (1973, Pl. 4, Figs. 17-19).

Nitzschia sp. 1-Plate 1, Figure 5.

Two rather slender specimens with inflated ends found in Samples $451-2-1,43-44 \mathrm{~cm}$ and $453-1-1,34-35 \mathrm{~cm}$, both of Pleistocene age ( $B$. invaginata Zone of the radiolarian zonation), could not be properly identified. 
Rhizosolenia bergonii Peragallo.

One fairly well preserved specimen was found in the late Pleistocene Sample 454A-1-3, 82-83 cm.

Rhizosolenia sp.

Two poorly preserved specimens, but with broad end of the valve at the apical process, were noted in Samples 451-2-6, 8-9 cm (late Pliocene) and 460-1-4, 140-141 cm (Pleistocene).

Thalassionema sp.-Plate 2, Figure 5.

Complete or broken specimens belonging to this genus were found in most samples listed in Table 1, and are recorded from Holes $450,451,452,453,454,454 \mathrm{~A}, 456 \mathrm{~A}, 458 \mathrm{~A}$ (common), 459, 460, and $460 \mathrm{~A}$.

Thalassiosira sp.-Plate 2, Figure 7.

Representatives of this genus, together with Thalassionema sp., are among the more common forms in the present material. They occur in the Pleistocene of Holes 449, 450, 451, 452, 456A, 458, 459,460 , and $460 \mathrm{~A}$, and are also present in the Pliocene of Hole 451. For details see Table 1. One specimen from Sample 450-1-1, $59-52 \mathrm{~cm}$, shown in Plate 2, Figure 2, was identified by $R$. Simonsen as Thalassiosira leptopus (Grunow) Hasle and Fryxell (syn. Coscinodiscus lineatus Ehrenberg).

Pseudotriceratium Wallichii (Ralfs in Pritchard)-Plate 2, Figure 8. Rare specimens were noted in the late Pleistocene of Holes 450 and 453.

\section{SILICOFLAGELLATES}

The occurrence of silicoflagellates in the present material is restricted to the Quaternary, with the exception of Hole 451 in which they were also found in the Pliocene. Because of their scarce occurrence in only some of the holes drilled, a detailed zonation is not attempted. Information on the systematics can be found in Locker (1974), Martini (1976), and Bukry (197). The following species were identified and are included in Table 1:

Dictyocha aculeata (Lemmermann)-Plate 3, Figure 1.

Several specimens were found in the Quaternary of Holes 449, 450, $451,452,453$, and 458.

Dictyocha $\mathrm{cf}$. epiodon Haeckel-Plate 3, Figure 2.

All forms with more or less elongated rectangular outline with four radial spines, and a vertical central bar supported by four apical rods are included here. This silicoflagellate is rare in the Quaternary of Hole 450 and 451 , but fairly common in the early Pliocene of Hole 451

Dictyocha cf. fibula Ehrenberg.

Two broken specimens, with a more or less elongated quadrate basal ring with four radial spines and a horizontal central bar supported by four apical rods were found in Sample 451-1,CC (early Pleistocene).

Dictyocha messanensis Haeckel-Plate 3, Figures 3 and 4.

Forms with quadrate basal ring and a spine on the central bar are frequently found in the Quaternary of Holes 450, 451, 452, 453, $454,454 \mathrm{~A}$, and $458 \mathrm{~A}$. For details see Table 1.

Dictyocha pentagona (Schulz)-Plate 3, Figure 9.

A single large specimen was found in Sample 449-2-1, 42-43 cm, where also a mass occurrence of the diatom Ethmodiscus rex was noted. It is probably displaced, since its original range is from the Eocene to the lower Miocene.

Distephanus quinquangellus Bukry and Foster-Plate 3, Figure 5. A single specimen was noted in the early Pliocene Sample 451-4-1, 9-10 cm.

Distephanus speculum (Ehrenberg).

Two specimens were found in the early Pliocene Sample 451-4-1, $9-10 \mathrm{~cm}$.

Samples in which Dictyocha aculeata was found probably belong to the late Quaternary Dictyocha aculeata Zone, and Sample 451-4-1, $9-10 \mathrm{~cm}$ may be placed in the late Miocene to early Pliocene Dictyocha "fibula" Zone (Martini, 1976). Mesocena quadrangula Haeckel was not found, and placement of the remaining samples containing silicoflagellates is impossible.

\section{SPONGE SPICULES}

A variety of sponge spicules were found in the Quaternary of nearly all holes, and also in the Pliocene of Hole 451. Sponge spicules, at least certain types, seem to belong to the solution-resistant siliceous forms and are often the only fossils left in solution-effected, siliceous assemblages as indicated by numerous samples from the Eocene of the North Sea Basin and the Norwegian Greenland Sea (Leg 38). In the present material, sponge spicules are much more common in levels with a high concentration of the large diatom Ethmodiscus rex, which is also believed to be a solution-resistant species (Mikkelsen, 1977), than in samples with a variety of diatoms.

Spicules in a living sponge are commonly of several types; also a certain spicule form may have been produced by different sponge species. For this reason simple descriptive terms are used as suggested by Schulze and Lendenfeld (1889), which are also used in more or less the same sense by more recent workers (e.g., Bukry, 1978).

Amphiaster III (noded)-Plate 3, Figure 11; Plate 4, Figures 1, 4, 5. A rod with three rays extending from both ends and with a rough (in some cases, noded) surface. Present in fairly large numbers in the Pleistocene sediments of Holes 449, 450, 451, 453, 459, and of Site 460. Some specimens in Sample 459-SP3-1, 70-71 cm even show spines on their surface.

Amphiaster III (smooth).

A rod with three rays extending from both ends, but with a smooth surface. Rare specimens were found in the Quaternary of Holes 450,452 , and 460 .

Amphiaster IV-Plate 4, Figure 6.

A rod with four rays extending prior to each end. It is rare in the Pleistocene Samples 450-1-1, 110-111 cm and 460A-3-3, 77-78 cm.

Amphiox (smooth)-Plate 4, Figures 3 and 9.

Simple curved or straight monaxon with two equally pointed ends (oxea in Bukry, 1978). Present in fairly large numbers in Pleistocene sediments of Holes 449, 450, 451, 453, 458, 460, 460A; it is also found in the Pliocene interval of Hole 451 .

Euaster VIII.

Aster with eight rays of equal length extending from a central point. Only one specimen was found in Sample 449-2-1, 42-43 cm (late Pleistocene).

Sigma-Plate 3, Figure 8.

Spirally curved monaxon with pointed ends (curved oxea in Bukry, 1978). It is present in several specimens in the Pleistocene of Holes $449,450,460$, and $460 \mathrm{~A}$.

Strongyle.

Monaxon with two simple rounded ends. Only one sturdy specimen was found in Sample 460A-1-4, 110-111 cm (late Pleistocene).

Style (crooked)-Plate 4, Figure 7.

Monaxon with one rounded end bent downward, and the other end pointed. One specimen was recorded in Sample 458-1-5, 63-64 $\mathrm{cm}$ (late Pleistocene).

Style (rugose).

Monaxon with one rounded end and the other end pointed, and with a rough surface. One specimen was encountered in Sample 459-SP3-1, 70-71 cm.

Triaene.

Monaxon with one pointed end and a larger trifid end. Only one specimen was observed in Sample 451-4-1, 9-10 cm (early Pliocene).

Triod.

Simple triaxial form with pointed ends. Some specimens were found in late Pleistocene samples of Holes 451, 453, and 460.

Tylostyle-Plate 4, Figure 10.

Monaxon with one end pointed and the other bulbous. Several specimens were encountered in the Pleistocene of Holes 449, 450, 451 , and 455 . It is also present in the early Pliocene Sample $451-4-1,9-10 \mathrm{~cm}$.

Tylote (rugose).

Monaxon with slightly bulbous ends and rugose surface. One specimen was found in Sample 451-2-1, 43-44 cm (early Pleistocene).

Tylote (spinose)-Plate 4, Figure 8.

Monaxon with slightly bulbous ends and spinose surface. Several specimens are present in Samples 450-1-1, 50-52 cm and 450-1-1, $110-111 \mathrm{~cm}$.

Forma indet.

A monaxon with irregular outline and slightly noded surface was observed in Sample 451-2-6, 8-9 cm (late Pliocene). Another ques- 
tionable monaxon specimen was found in Sample 451-2-1, 43-44 $\mathrm{cm}$ (early Pleistocene).

\section{ENDOSKELETAL DINOFLAGELLATES}

Endoskeletal dinoflagellates are extremely rare in the present material. Only two species were found in the late Pleistocene of Legs 59 and 60. Foliactiniscus mirabilis Dumitricá was noted in Hole 451 (Plate 3, Figure 7), and Actiniscus pentasterias Ehrenberg was encountered in Holes 453 and 460 (Plate 3, Figure 6). For details see Table 1. Descriptions and discussion of these species may be found in Dumitrică (1973b).

\section{PHAEDARIAN RADIOLARIANS}

In Samples 41-2-3, 29-30 cm and 454A-1-3, 82-83 cm, both belonging to the late Pleistocene, rare specimens of the phaeodarian Lirella marina (Bailey) were noted (Plate 3, Figure 10). They represent the thick-walled variety of Dumitricá (1973a, p. 755). This species seems to be a common constituent of the marine Quaternary plankton in the southwest Pacific Ocean, and was recorded at several sites of Leg 21 (Dumitricà, 1973a).

\section{ACKNOWLEDGMENTS}

Thanks are due to the U.S. National Science Foundation and to the Chief Scientist, Deep Sea Drilling Project, for providing the samples of Leg 60. Data concerning the nannoplankton and radiolarians of Leg 60 were received by the shipboard paleontologists Dr. Howard Ellis and Dr. Stanley Kling, which are very much appreciated. I also want to thank Dr. Reimer Simonsen for valuable discussions and identification of some diatom species. The investigation was supported by the Deutsche Forschungsgemeinschaft. Scanning electron microscope pictures were taken by J. Tochtenhagen with a Stereoscan Mark 2, which was provided to the Geologisch-Paläontologisches Institut der Universitat Frankfurt am Main by the VW-Stiftung. My thanks go also to Dr. Stanley Kling and Dr. Reimer Simonsen for reviewing this paper.

\section{REFERENCES}

Bukry, D. 1978, Cenozoic coccolith, silicoflagellate, and diatom stratigraphy, Deep Sea Drilling Project Leg 44. In Benson, W. E., Sheridan, R. E., et al., Init. Repts. DSDP, 44: Washington (U.S. Govt. Printing Office), 807-863.

Dumitrică, P. 1973a. Phaeodarian radiolaria in southwest Pacific sediments cored during Leg 21 of the Deep Sea Drilling Project. In Burns, R. E., Andrews, J. E., et al., Init. Repts. DSDP, 21: Washington (U.S. Govt. Printing Office), 751-785.

Dumitrică, P. 1973b. Cenozoic endoskeletal dinoflagellates in southwestern Pacific sediments cored during Leg 21 of the DSDP. In Burns, R. E., Andrews, J. E., et al., Init. Repts. DSDP, 21: Washington (U.S. Govt. Printing Office), 819-835.

Gombos, A. M. 1977. Paleogene and Neogene diatoms from the Falkland Plateau and Malvinas Outer Basin: Leg 36, Deep Sea Drilling Project. In Barker, P. F., Dalziel, I.W.D., et al., Init. Repts. DSDP, 36: Washington (U.S. Govt. Printing Office), 575-687.

Jousé, A. P., Kozlova, O. G., and Muhina, V. V. 1971. Distribution of diatoms in the surface layer of sediment from the Pacific Ocean. In Funnell, B. M., and Riedel, W. R., The Micropalaeon- tology of Oceans: Cambridge (Cambridge University Press), 263-269.

Kozlova, O. G., 1971. The main features of diatom and silicoflagellate distribution in the Indian Ocean. In Funnell, B. M., and Riedel, W. R. (Eds.), The Micropalaeontology of Oceans: Cambridge (Cambridge University Press), 271-275.

Kroenke, L., Scott, R., et al., in press. Init. Repts. DSDP, 59: Washington (U.S. Govt. Printing Office).

Locker, S. 1974. Revision der Silicoflagellaten aus der mikrogeologischen Sammlung von L. G. Ehrenberg. Ecolog. Geol. Helvet, 67:631-646.

Martini, E., 1971. Standard Tertiary and Quaternary calcareous nannoplankton zonation. Proc. Sec. Plankt. Conf., Roma 1970, 2:739-785.

1976. Neogene and Quaternary silicoflagellates from the central Pacific Ocean. In Schlanger, S. O., Jackson, E. D., et al., Init. Repts. DSDP, 33: Washington (U.S. Govt. Printing Office), 439-449.

Mikkelsen, N., 1977. On the origin of Ethmodiscus ooze. Mar. Micropaleont., 2:35-46.

Muhina, V. V., 1971. Problems of diatom and silicoflagellate Quaternary stratigraphy in the equatorial Pacific Ocean. In Funnell, B. M., and Riedel, W. R. (Eds.), The Micropalaeontology of Oceans: Cambridge (Cambridge University Press), 423-431.

Nigrini, C. A., 1971. Radiolarian zones in the Quaternary of the equatorial Pacific Ocean. In Funnell, B. M., and Riedel, W. R. (Eds.), The Micropalaeontology of Oceans: Cambridge (Cambridge University Press), 443-461.

Perch-Nielsen, K., 1975. Late Cretaceous to Pleistocene archaeomonads, ebridians, endoskeletal dinoflagellates, and other siliceous microfossils from the subantarctic Southwest Pacific, DSDP, Leg 29. In Kennett, J. P., Houtz, R. E., et al., Init. Repts. DSDP, 29: Washington (U.S. Govt. Printing Office), 873-907. 1978. Eocene to Pliocene archaeomonads, ebridians, and endoskeletal dinoflagellates from the Norwegian Sea, DSDP Leg 38. In Talwani, M., Udintsev, G., et al., Init. Repts. DSDP, supplement volumes $38,39,40,41$ : Washington (U.S. Govt. Printing Office), $147-175$.

Pimm, A. C., Garrison, R. E., and Boyce, R. E., 1971. Sedimentology synthesis: lithology, chemistry and physical properties of sediments in the northwestern Pacific Ocean. In Fisher, A. G., Heezen, B.C., et al., Init. Repts. DSDP, Washington (U.S. Govt. Printing Office), 6:1131-1252.

Schrader, H. J., 1973. Cenozoic diatoms from the Northeast Pacific, Leg 18. In Kulm, L. D., von Huene, R., et al., Init. Repts. DSDP, 18: Washington (U.S. Govt. Printing Office), 673-793.

1976a. Marine diatom biostratigraphy of selected samples from the equatorial Pacific, DSDP Leg 33. In Schlanger, S. O., Jackson, E. D., et al., Init. Repts. DSDP, 33: Washington (U.S. Govt. Printing Office), 491-492.

,1976b. Cenozoic planktonic diatom biostratigraphy of the southern Pacific Ocean. In Hollister, C. D., Craddock, C., et al., Init. Repts. DSDP, 35: Washington (U.S. Govt. Printing Office), 605-671.

Schulze, F. E., and Lendenfeld, R. von, 1889. Uber die Bezeichnung der Spongiennadeln. Abh. königl. Preuss. Akad. Wiss. Berlin, 1889:1-35.

Simonsen, R., 1974. The diatom plankton of the Indian Ocean Expedition of R. V. "Meteor" 1964-65. "Meteor" Forschungsergebn., D 19:1-107. 

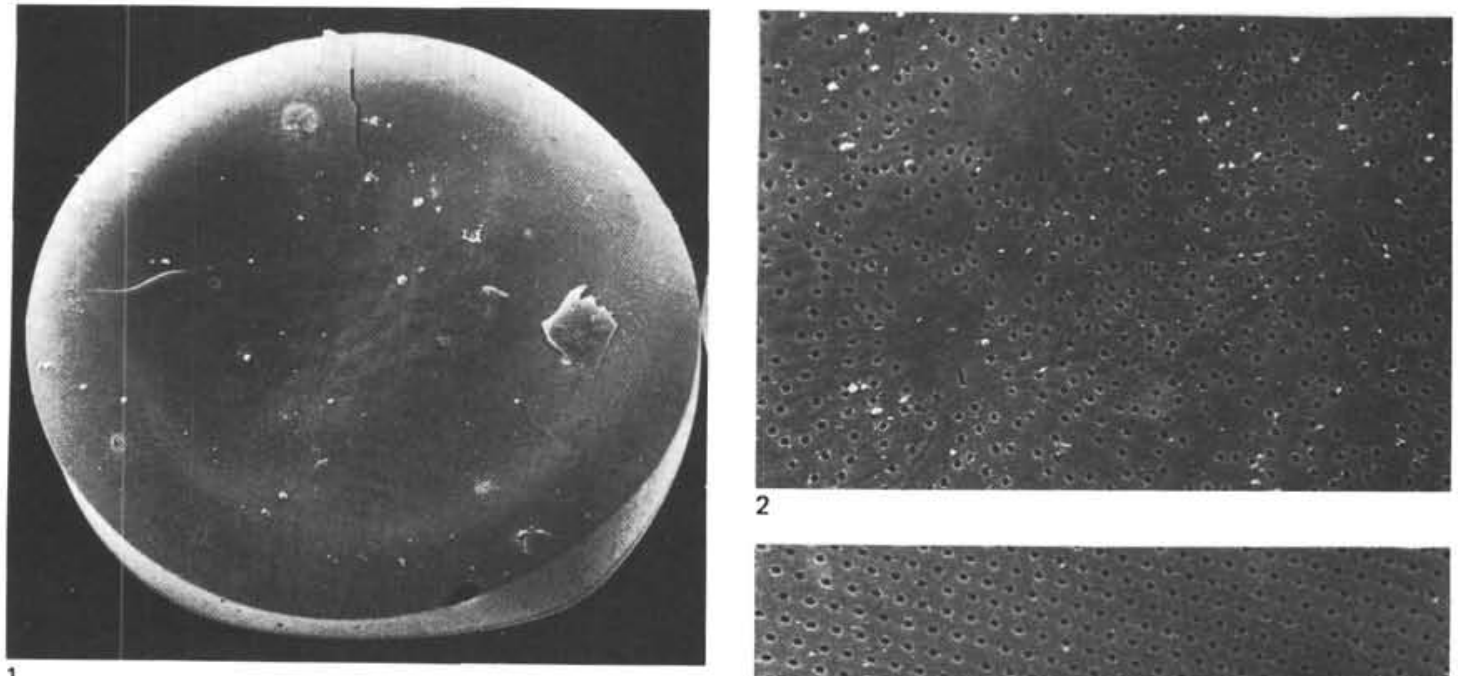

2
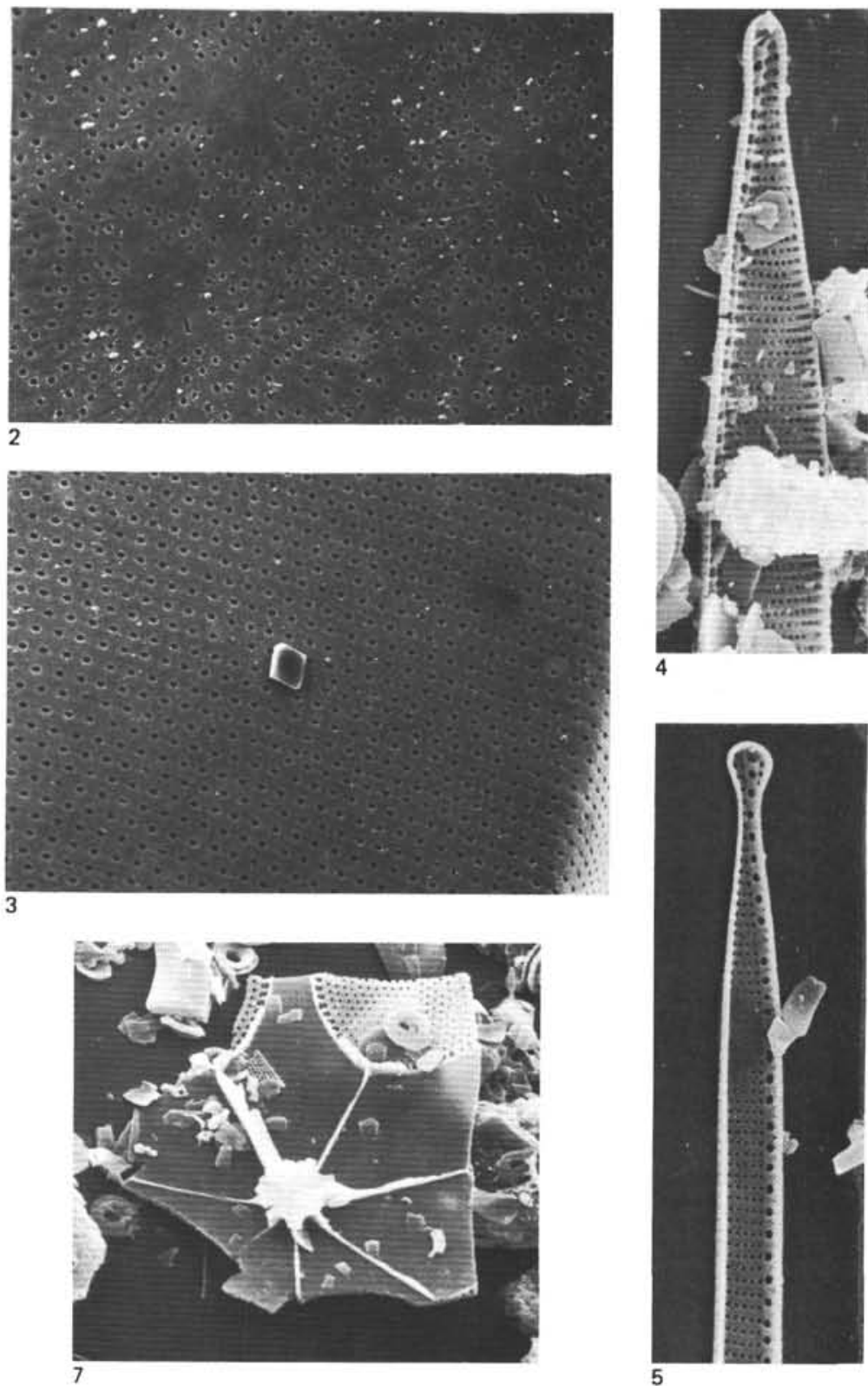

Plate 1. Pleistocene diatoms from the Philippine Sea.

Figures 1-3. Ethmodiscus rex Wallich. 1. Distal side of half valve, scanning electron microscope $\times 85.2$. Arrangement of pores in the central area, scanning electron microscope $\times 1000$. 3. Arrangement of pores near the rim, scanning electron microscope $\times 1000$. Sample 449-2-1, 42-43 cm, late Pleistocene.

Figure 4. Nitzschia $\mathrm{cf}$. bicapitata Cleve. Scanning electron microscope $\times 4750$. Sample $451-2-1,43-44 \mathrm{~cm}$, early Pleistocene.
Figure 5. Nitzschia sp. Scanning electron microscope $\times 5000$. Sample 451-2-1, 43-44 cm, early Pleistocene.

Figure 6. Nitzschia bicapitata Cleve. Scanning electron microscope $\times 5000$. Sample 451-1,CC, early Pleistocene.

Figure 7. Asterolampra marylandica Ehrenberg. Scanning electron microscope $\times 2000$. Broken, central part. Sample $451-1$, CC, early Pleistocene. 

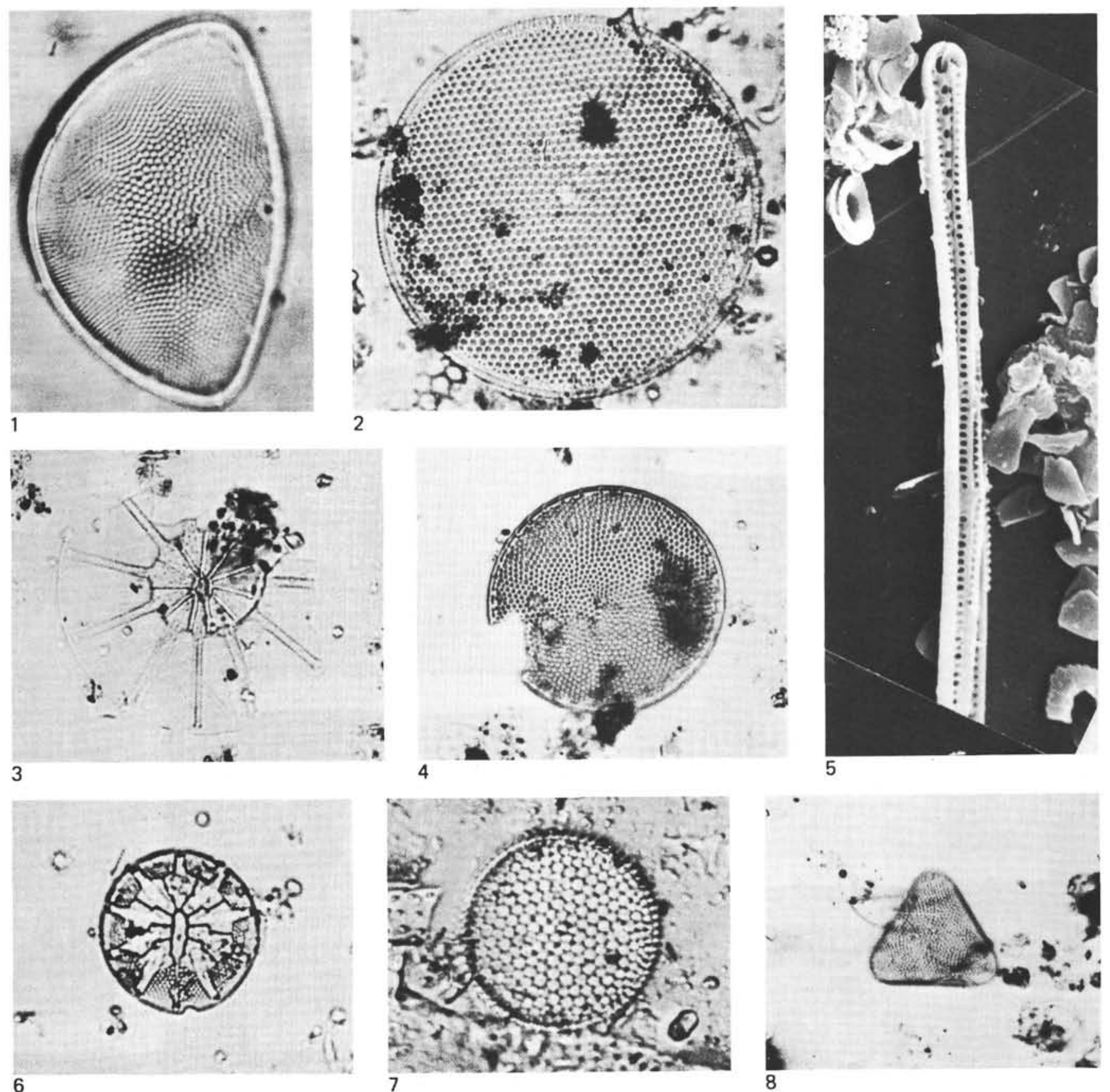

Plate 2. Pleistocene diatoms from the Philippine Sea. All except Figure 5 light microscope and magnified approximately $\times 580$.

Figure 1. Hemidiscus cuneiformis Wallich. Sample 449-2-1, $42-43 \mathrm{~cm}$. Figure 2. Thalassiosira leptopus (Grun.). Sample 450-1-1, 50-52 cm. Figure 3. Asteromphalus hookeri Ehrenberg. Sample 453-2-1, 60-61 $\mathrm{cm}$.

Figure 4. Coscinodiscus africanus Janisch. Sample 454A-1-3, 82-83 $\mathrm{cm}$.
Figure 5. Thalassionema sp., scanning electron microscope $\times 5000$, Sample 451-1,CC,

Figure 6. Asteromphalus cf. brookei Bailey Sample 453-2-1, 60-61 $\mathrm{cm}$.

Figure 7. Thalassiosira sp. Sample 449-2-1, $42-43 \mathrm{~cm}$.

Figure 8. Pseudotriceratium Wallichi (Ralfs in Pritchard) Sample $453-2-1,60-61 \mathrm{~cm}$. 


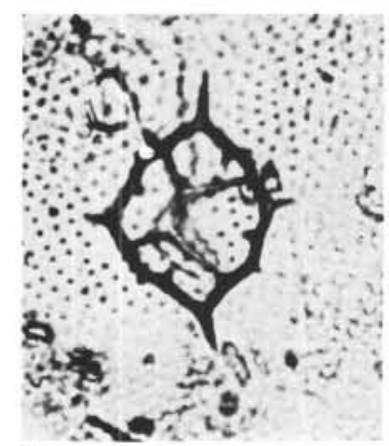

1

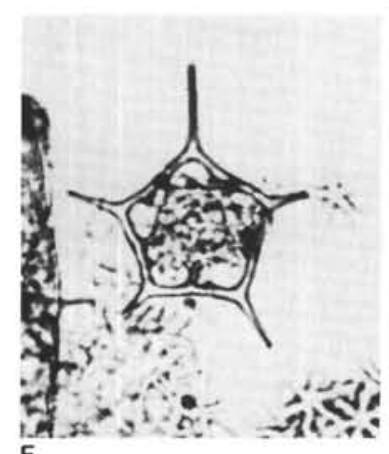

5

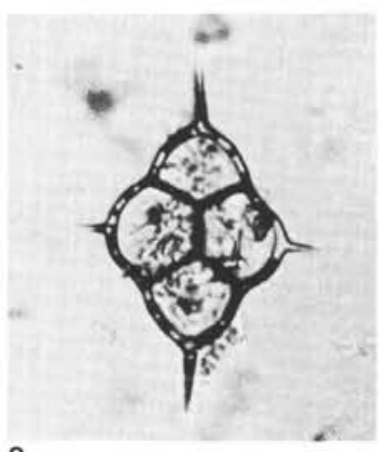

2

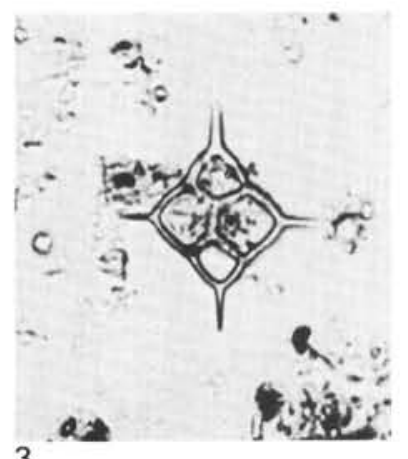

3

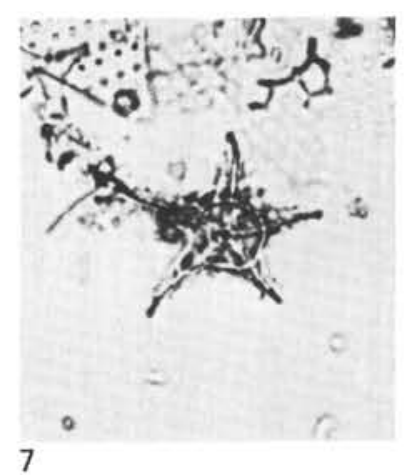

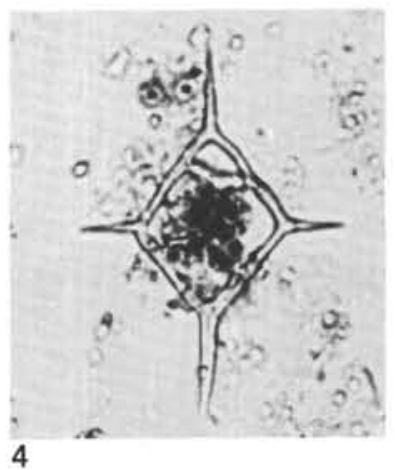

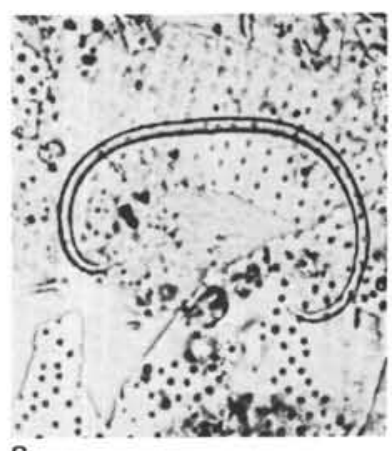

8

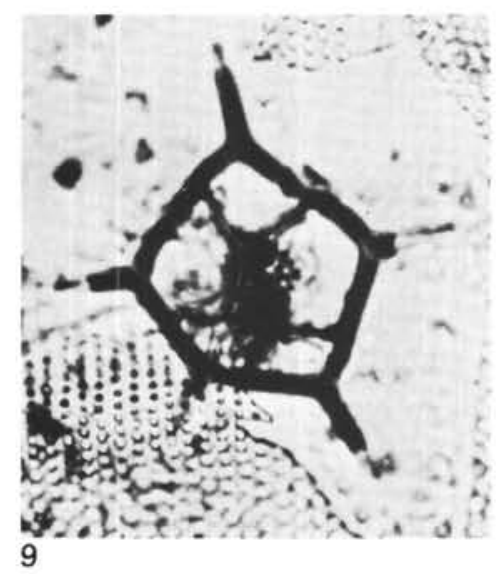

Plate 3. Pliocene and Pleistocene silicoflagellates, endoskeletal dinoflagellates, sponge spicules, and a phaeodarian radiolarian from the Philippine Sea. All specimens light microscope and approximately $\times 580$.

Figure 1. Dictyocha aculeata (Lemmermann). Sample 449-2-1, 42-43 $\mathrm{cm}$, late Pleistocene.

Figure 2. Dictyocha cf. epiodon Ehrenberg. Sample 451-4-1, 9-10 cm, early Pliocene.

Figures 3, 4. Dictyocha messanensis Haeckel. 3. Sample 458-1-5, 63-64 $\mathrm{cm}$, late Pleistocene. 4. Sample 450-1-1, 50-52 cm, late Pleistocene.

Figure 5. Distephanus quinquangellus Bukry and Foster. Sample 451-4-1, 9-10 cm, early Pliocene.
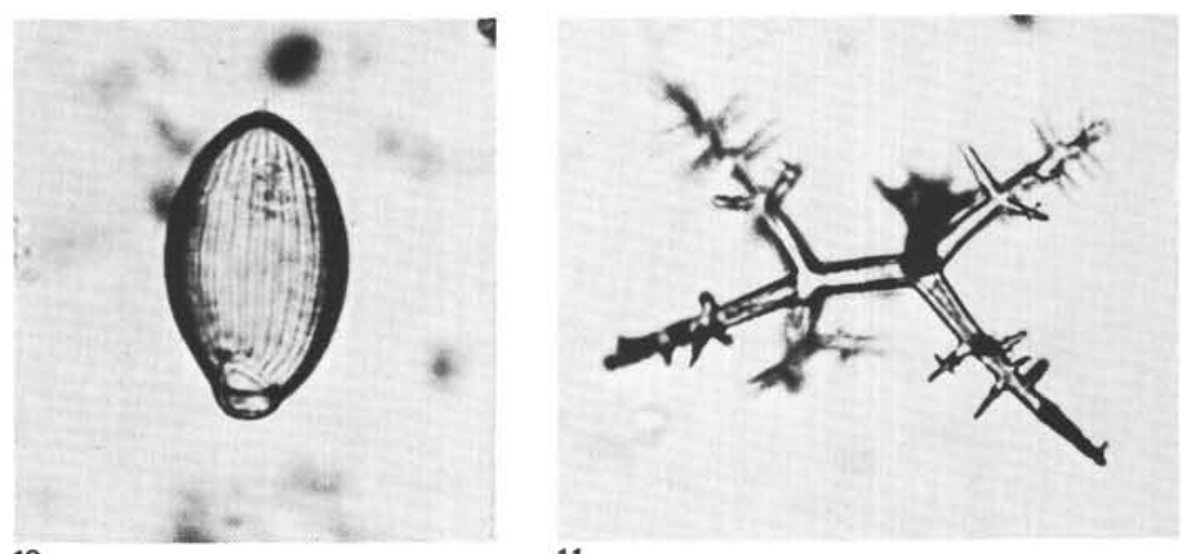

11

Figure 6. Foliactiniscus mirabilis Dumitricá. Sample 451-2-1, 43-44 $\mathrm{cm}$, early Pleistocene.

Figure 7. Actiniscus pentasterias Ehrenberg. Sample 453-1-1, 34-35 $\mathrm{cm}$, late Pleistocene.

Figure 8. Sigma. Sample 460-1-4, 140-141 cm, late Pleistocene.

Figure 9. Dictyocha pentagona (Schulz). Sample 449-2-1, 42-43 cm, late Pleistocene (displaced from the Paleogene).

Figure 10. Lirella marina (Bailey). Sample $454 \mathrm{~A}-1-3,82-83 \mathrm{~cm}$, late Pleistocene.

Figure 11. Amphiaster III (spinose). Sample 459-SP3-1, 70-71 cm, Pleistocene. 

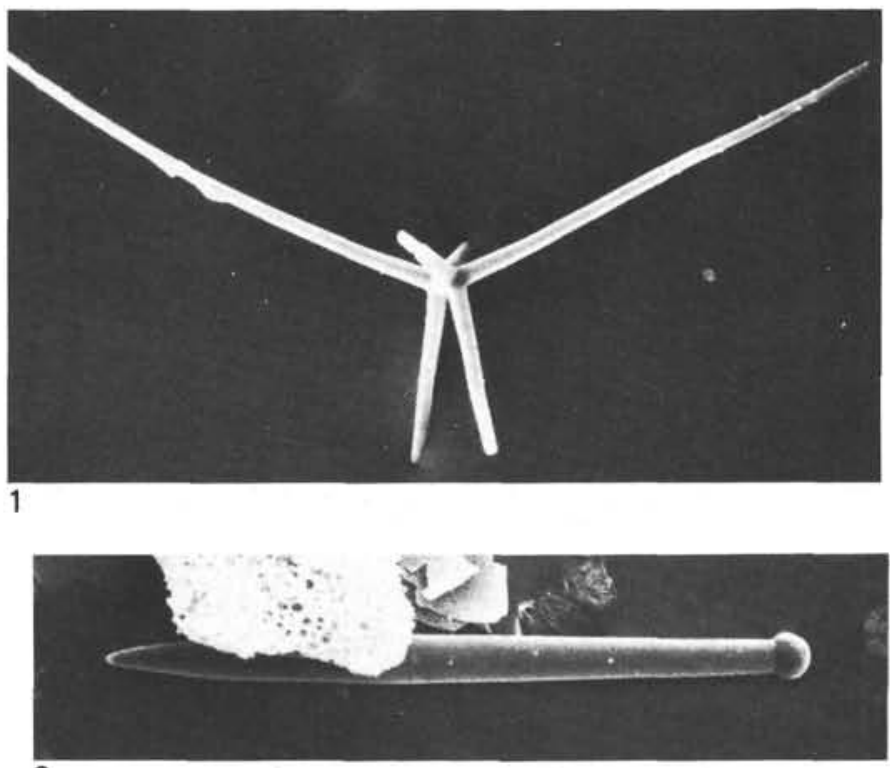

2
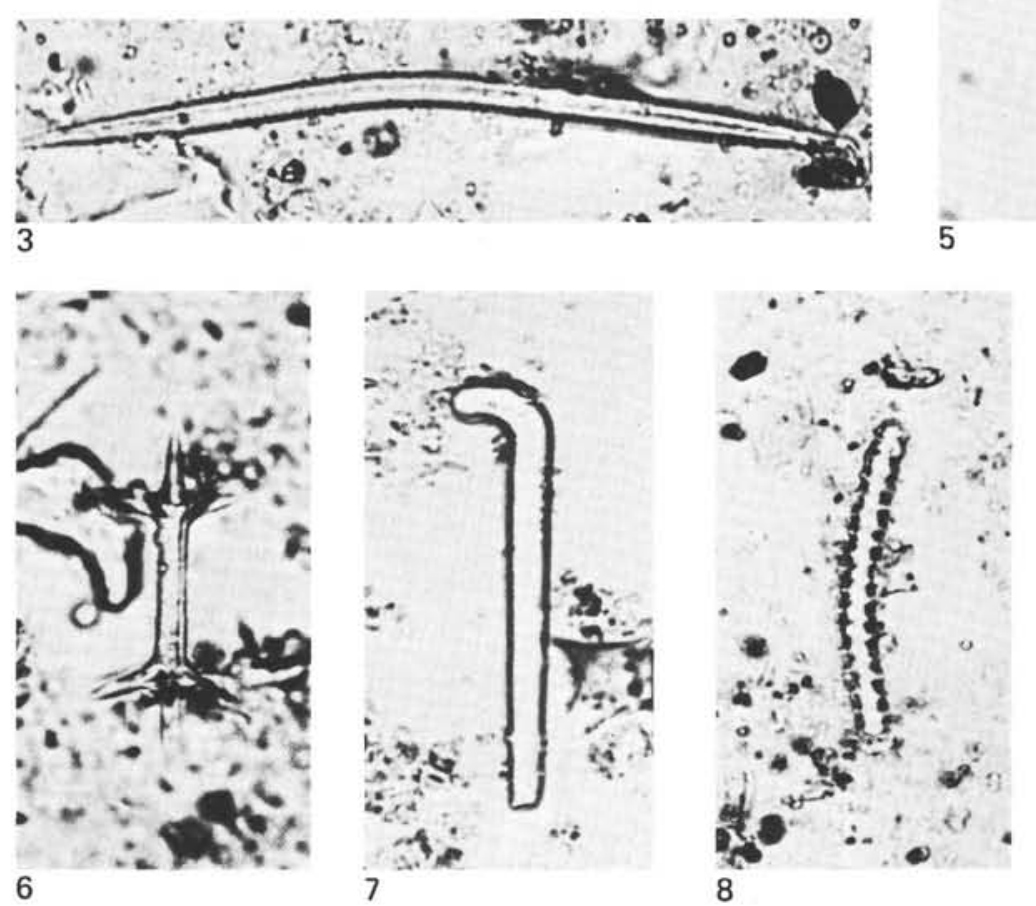

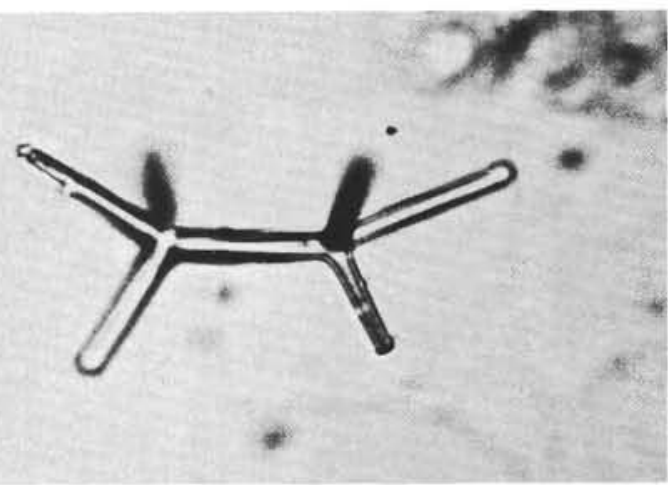

4
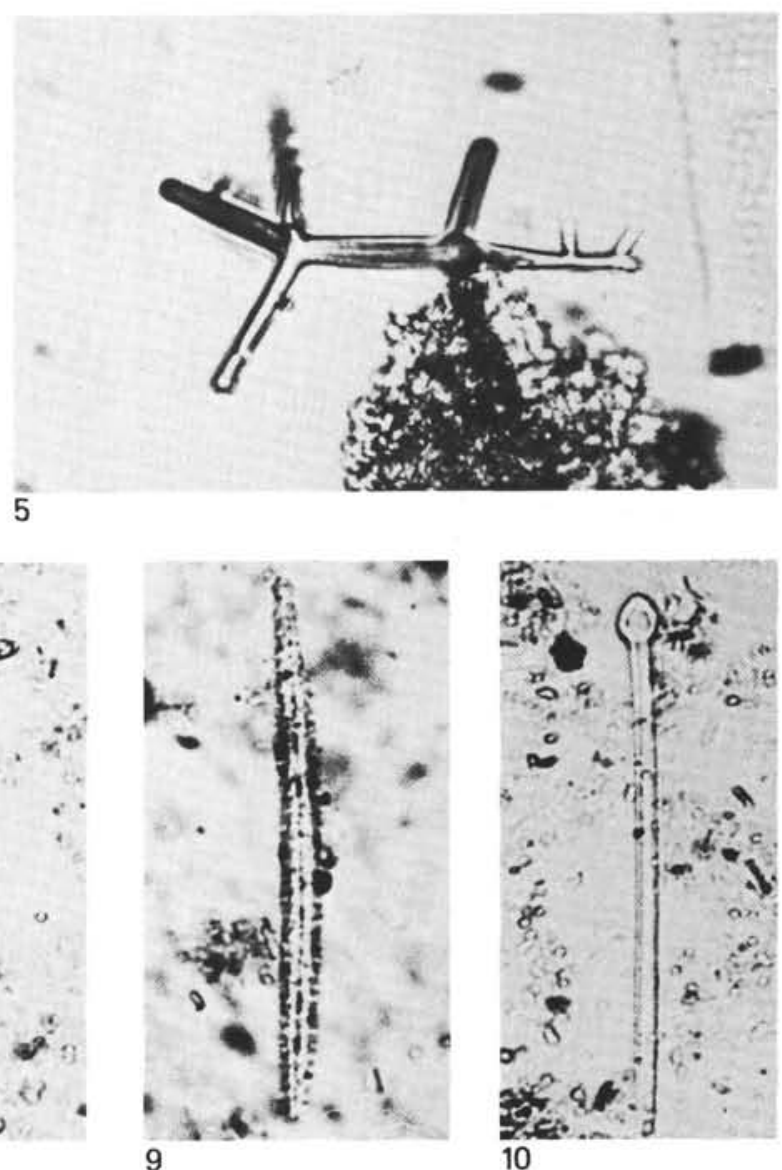

Plate 4. Pleistocene sponge spicules from the Philippine Sea.

Figure 1. Amphiaster III, scanning electron microscope $\times 200$. Sample 459-SP3-1, 70-71 cm.

Figure 2. Tylostyle, scanning electron microscope $\times 200$. Sample 459-SP3-1, 70-71 cm.

Figure 3. Amphiox, light microscope $\times 580$. Sample 450-1-1, 110-111 $\mathrm{cm}$.

Figures 4, 5. Amphiaster III (noded), light microscope $\times 580$. Sample 459-SP3-1, 70-71 cm.
Figure 6. Amphiaster IV, light microscope $\times 580$. Sample 450-1-1, $110-111 \mathrm{~cm}$.

Figure 7. Style (crooked), light microscope $\times 580$. Sample 458-1-5, $63-64 \mathrm{~cm}$.

Figure 8 . Tylote (spinose), light microscope $\times 580$. Sample $450-1-1$, $50-52 \mathrm{~cm}$.

Figure 9. Amphiox (rugose), light microscope $\times 580$. Sample 450-1-1, $110-111 \mathrm{~cm}$.

Figure 10. Tylostyle, light microscope $\times 580$. Sample 450-1-1, 50-52 $\mathrm{cm}$. 